\title{
Porażki EKG w diagnostyce chorób prawego serca
}

\section{Failures of ECG assessment in diagnostic of right heart diseases}

\author{
Piotr Bienias, Piotr Pruszczyk \\ Klinika Chorób Wewnętrznych i Kardiologii z Centrum Diagnostyki i Leczenia \\ ŻyInej Choroby Zakrzepowo-Zatorowej Warszawskiego Uniwersytetu Medycznego
}

\section{Streszczenie}

Badanie elektrokardiograficzne (EKG) cechuje niedostateczna czułość i swoistość, by mogło stanowić pojedyncze narzędzie w wykrywaniu przerostu lub powiększenia prawej komory serca. Brak typowych odchyleń w EKG nie wyklucza również nadciśnienia płucnego. Objawy kliniczne i obciążający wywiad powinny ukierunkowywać na poszerzenie diagnostyki prawej komory o badanie echokardiograficzne. W pracy przedstawiono 2 przypadki chorych z potwierdzonym przerostem prawej komory i nadciśnieniem płucnym bez typowych dla tych stanów zmian w EKG.

Słowa kluczowe: elektrokardiografia, przerost prawej komory, nadciśnienie płucne

Folia Cardiologica 2015; 10, supl. C: 21-23

\section{Opisy przypadków}

Obecność typowych dla przerostu prawej komory (RV, right ventricle) i prawego przedsionka nieprawidłowości w zapisie elektrokardiograficznym (EKG) może sugerować lub wspierać rozpoznanie różnych postaci nadciśnienia płucnego (PH, pulmonary hypertension) [1-3]. Wykazano, że wśród pacjentów z przewlekłym i ciężkim PH elektrokardiograficzne cechy przerostu RV występują u 80-85\% chorych [2].

Rycina 1 przedstawia EKG 68-letniego mężczyzny z narastającą dusznością wysiłkową, utrwalonym migotaniem przedsionków, po przebytej pół roku wcześniej ostrej zatorowości płucnej. W EKG nie stwierdzono żadnych cech przerostu RV. W echo serca natomiast zobrazowano powiększenie RV (36 mm) oraz wysokie ciśnienie w tętnicy płucnej (skurczowe $72 \mathrm{~mm} \mathrm{Hg}$ ), co potwierdzono w cewnikowaniu prawego serca. Niski woltaż zespołów QRS w odprowadzeniach kończynowych nie wynikał z obecności płynu w jamie osierdzia, a pacjent nie był otyły. Po wykluczeniu choroby wieńcowej (prawidłowy obraz w koronarograffii) chorego poddano kardiochirurgicznej trombarterektomii tętnic płucnych, uzyskując wyraźną poprawę.

Rycina 2 przedstawia EKG 92-letniej kobiety, która w przeszłości paliła papierosy, a obecnie zgłosiła się do szpitala z powodu narastającej duszności spoczynkowej (bez objawów bronchospastycznych i zastoju płucnego w badaniu klinicznym). W wykonanym badaniu echokardiograficznym serca stwierdzono powiększenie RV (32 mm), istotnie podwyższone ciśnienie w tętnicy płucnej (skurczowe $94 \mathrm{~mm} \mathrm{Hg}$ ) oraz umiarkowaną stenozę aortalną z niedużym przerostem lewej komory. Badanie angio-CT tętnic płucnych nie wykazało obecności skrzeplin, stwierdzono natomiast tapetującą postać raka płuc. W EKG pacjentki także nie są spełnione kryteria przerostu RV (przy obecności blok prawej odnogi i przedniej wiązki lewej odnogi pęczka Hisa [RBBB, right bundle branch block/LAH, left anterior hemiblock]), aczkolwiek woltaż zespołów QRS jest relatywnie wysoki, a amplituda zespołów rsR' w odprowadzeniach V1-V2 wynosi $13-14 \mathrm{~mm}$.

Należy pamiętać, że EKG ma niedostateczną czułość i swoistość, by stanowić pojedyncze narzędzie w wykrywaniu

Adres do korespondencji: dr n. med. Piotr Bienias, Klinika Chorób Wewnętrznych i Kardiologii, Warszawski Uniwersytet Medyczny, Szpital Kliniczny Dzieciątka Jezus, ul. Lindleya 4, 02-005 Warszawa, tel. 2250211 44, faks 2250221 42, e-mail: pbienias@mp.pl 


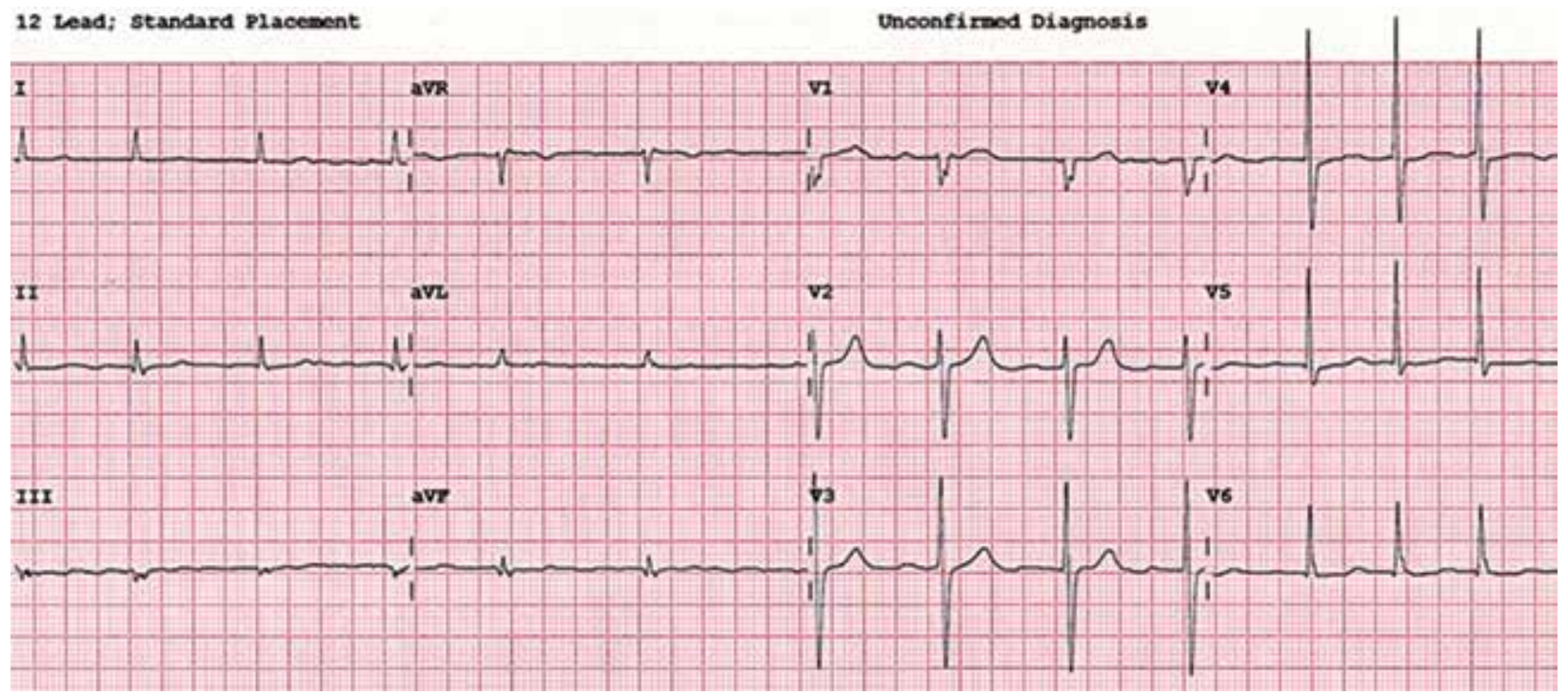

Rycina 1. Zapis elektrokardiograficzny chorego z potwierdzonym w cewnikowaniu prawego serca, istotnym zakrzepowo-zatorowym nadciśnieniem płucnym oraz powiększeniem i przerostem prawej komory w badaniu echokardiograficznym - migotanie przedsionków, niski woltaż zespołów QRS w odprowadzeniach kończynowych $(25 \mathrm{~mm} / \mathrm{s}, 10 \mathrm{~mm} / \mathrm{mV})$

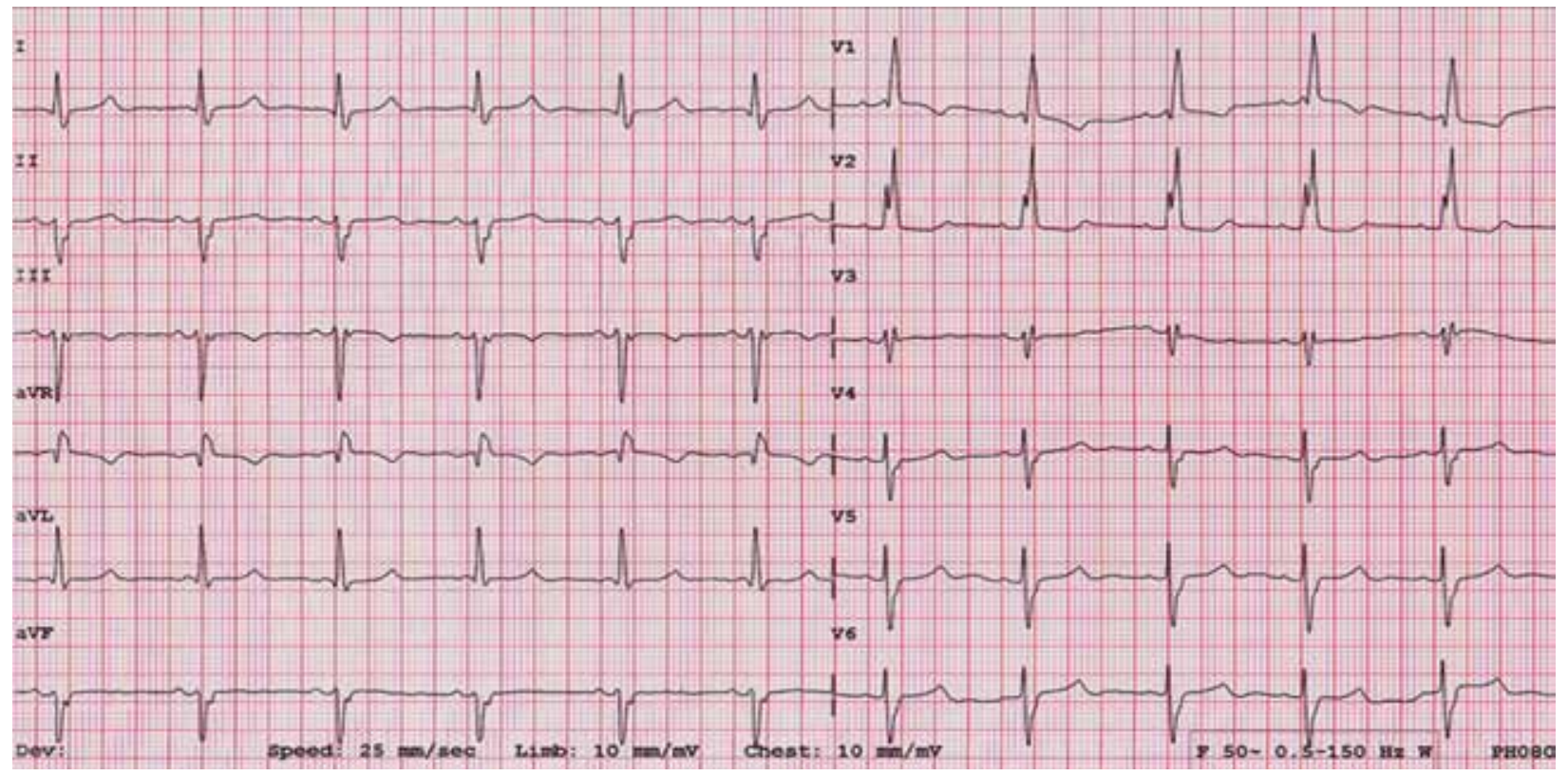

Rycina 2. Zapis elektrokardiograficzny chorej z nadciśnieniem płucnym wtórnym do chorób płuc i hipoksji (tapetujący rak płuca) oraz umiarkowaną stenozą aortalną z niedużym przerostem lewej komory - rytm zatokowy, blok prawej odnogi i przedniej wiązki lewej odnogi pęczka Hisa $(25 \mathrm{~mm} / \mathrm{s}, 10 \mathrm{~mm} / \mathrm{mV})$

przerostu/powiększenia RV oraz że brak typowych odchyleń w EKG nie wyklucza PH. Najczęstsze przyczyny braku charakterystycznych dla przerostu RV zmian w EKG to otyłość, płyn w jamie osierdzia i rozedma płuc $[2,3]$.

\section{Konflikt interesów}

Autorzy deklarują brak konfliktu interesów. 


\section{Abstract}

An electrocardiogram is characterized by an insufficient sensitivity and specificity to be a single tool in the recognition of hypertrophy or enlargement of the right ventricle. Absence of typical abnormalities in electrocardiography do not exclude pulmonary hypertension either. Therefore clinical symptoms and specific signs in medical past history should indicate to perform echocardiography. The paper presents 2 cases of patients with confirmed right ventricle hypertrophy and pulmonary hypertension without typical electrocardiographic abnormalities.

Key words: electrocardiography, right heart hypertrophy, pulmonary hypertension

Folia Cardiologica 2015; 10, supl. C: $21-23$

\section{Piśmiennictwo}

1. Zalecenia dotyczące rozpoznań elektrokardiograficznych. Kardiol. Pol. 2010; 68 (supl. IV): S335-S389.

2. Wytyczne ESC dotyczące rozpoznawania i leczenia nadciśnienia płucnego. Kardiol. Pol. 2009; 67 (supl. 7): S491-S544.
3. Bienias P., Rymarczyk Z. Badanie elektrokardiograficzne w zatorowości płucnej. W: Pruszczyk P., Ciurzyński M., Kostrubiec M. (red.). ŻyIna choroba zakrzepowo-zatorowa. Medical Tribune Polska, Warszawa 20120: 68-74. 